\title{
Prevalence of salivary epstein-barr virus in potentially malignant oral disorders and oral squamous cell carcinoma
}

\author{
Leticia Bagan 1, María-Dolores Ocete-Monchon 2, Manuel Leopoldo-Rodado ${ }^{3}$, Judith Murillo-Cortes ${ }^{4}$, \\ Jose-M. Díaz-Fernández ${ }^{4}$, Rafael Medina-Gonzalez ${ }^{2}$, Concepción Gimeno-Cardona ${ }^{5}$, Jose-V. Bagan ${ }^{6}$
}

\footnotetext{
${ }^{1}$ Associate Professor of Oral Medicine, European University of Valencia, Spain

${ }^{2}$ Consultant Microbiology Service. University General Hospital, Valencia

${ }^{3}$ Consultant in Oral and Maxillofacial Surgery. Service of Stomatology and Maxillofacial Surgery, Valencia

${ }^{4}$ Head Section in Oral and Maxillofacial Surgery. Service of Stomatology and Maxillofacial Surgery, Valencia

${ }^{5}$ Professor and Head Service of Microbiology. Valencia University and University General Hospital Valencia

${ }^{6}$ Professor and Head Service of Stomatology and Maxillofacial Surgery. Valencia University and University General Hospital Valencia, Spain
}

Correspondence:

Oral Medicine Department

C/ Gasco Oliag 1

46010 Valencia, Spain

bagan@uv.es

\begin{abstract}
Bagan L, Ocete-Monchon MD, Leopoldo-Rodado M, Murillo-Cortes J, Díaz-Fernández JM, Medina-Gonzalez R, Gimeno-Cardona C, Bagan JV. Prevalence of salivary epstein-barr virus in potentially malignant oral disorders and oral squamous cell carcinoma. Med Oral Patol Oral Cir Bucal. 2016 Mar 1;21 (2):e157-60.

http://www.medicinaoral.com/medoralfree $01 / \mathrm{v} 21$ i2/medoralv21i2p157.pdf
\end{abstract}

Received: $18 / 04 / 2015$

Accepted: 13/01/2016

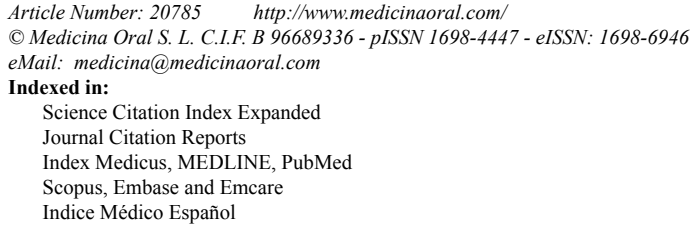

\begin{abstract}
Background: To analyze the presence of salivary Epstein-Barr virus (EBV) DNA in oral squamous cell carcinoma and potentially malignant oral disorders.

Material and Methods: Three groups were studied: Group 1 (12 oral squamous cell carcinomas (OSCC)), Group 2 (12 potentially malignant oral disorders (PMD)) and Group 3 (47 healthy controls). EBV DNA salivary analysis was performed by PCR.

Results: The highest percentage of positive salivary EBV DNA corresponded to the OSCC group (58.3\%), followed by the PMD group (41.7\%) and the controls (40.4\%). The differences between groups were not statistically significant, however $(p>0.05)$.

Conclusions: Salivary EBV DNA was more prevalent in OSCC than in PMD or the controls.
\end{abstract}

Key words: EBV DNA, saliva, oral squamous cell carcinoma, oral leukoplakia. 


\section{Introduction}

Epstein-Barr virus (EBV) is a very well known oncogenic human herpes virus that has been implicated in several malignant tumors affecting epithelial cells and B lymphocytes (1).

The prevalence of EBV in the general population is very high, and there are nearly 200,000 new cases of infection in the world every year. In the first two decades of life EBV infects $90 \%$ of all individuals. According to Ueda et al., EBV is a reversible latent infection in $\mathrm{B}$ cells (2).

It is believed that EBV initially penetrates and multiplies within epithelial cells, followed by release into saliva, affecting B lymphocytes and spreading throughout the rest of the body. However, most affected individuals are asymptomatic, despite detection of the virus in different body secretions and blood (3).

Saliva plays a significant role in the capacity of EBV to become transmitted to other people. The virus is infective when present in saliva, both in asymptomatic and symptomatic carriers. EBV is released into saliva from the epithelial cells, and it is in this fluid where maximum infectious capacity is observed (1). On the other hand, EBV is found not only in B cells but also in nasopharyngeal carcinomas (4).

Salivary EBV has been analyzed in several oral diseases, particularly in patients with periodontal problems (5-9). In 2007 we already addressed the presence of EBV in potentially malignant disorders (PMD) and in oral squamous cell carcinoma (OSCC), though involving a smaller number of cases (10). However, there have been recent controversial findings in the literature regarding the association between EBV and OSCC. The present study analyzes the frequency of EBV DNA positivity in OSCC and PMD comparing with controls.

\section{Material and Methods}

Three groups were studied: Group 1 (12 OSCC), Group 2 (12 PMD) and Group 3 (47 healthy controls).

There were no clinical differences among the three groups regarding age or gender $(p>0.05)$.

Oral squamous cell carcinoma was diagnosed from an incisional biopsy. In the leukoplakia group (Group 2) we also obtained a biopsy to establish the diagnosis following the criteria of Carrard et al. (11).

The study was approved by the Ethics Committee of the University of Valencia (Spain), and informed consent was obtained from each patient.

Whole non-stimulated saliva was obtained in all cases according to the criteria of Navacek et al. (12). Saliva samples were immediately stored and frozen at $-80^{\circ}$ until EBV DNA analysis.

EBV DNA salivary analysis was performed by PCR following the methodology described elsewhere (3). Saliva samples were obtained and DNA was extracted as reported (2). EBV DNA levels were determined by qualitative real-time PCR (qPCR) targeting the EBV Gen LMP1 region.

The present case-control study evaluated the presence and percentage of positive findings regarding EBV DNA and analyzed the association of the virus to the different groups using the $\chi 2$ test. Statistical significance was considered for $p<0.05$.

\section{Results}

The highest percentage of positive salivary EBV DNA corresponded to the OSCC group, followed by the leukoplakia (PMD) group and the controls (Table 1). The differences between groups were not statistically significant, however $(p>0.05)$ (Table 2).

Four of the 9 cases of proliferative verrucous leukoplakia (44.4\%) presented positive salivary EBV DNA. In those cases with only homogeneous leukoplastic areas, the positivity rate was lower (33.3\%).

\section{Discussion}

Epstein-Barr virus is very common in normal individuals of the general population. According to Ueda et al. (2), its prevalence may reach $90 \%$ in saliva. The virus can penetrate and multiply within the epithelial cells, followed by release into saliva.

The salivary EBV DNA detection rate and consequently shedding of the virus in healthy persons ranges from $22-90 \%$ (3). Despite the variability among authors, the detection rate is usually high in healthy controls. In this respect we found $40.4 \%$ of our controls to be positive for DNA EBV.

Epstein-Barr virus DNA in saliva has been analyzed in several diseases such as connective tissue disorders (13), adverse drug reactions with eosinophilia and systemic symptoms (DRESS) (14), periimplantitis (15), HIV infection $(3,16)$, periodontal disease (6) and in transplant patients (17).

In cancer patients, EBV in saliva has been described as a useful tool in nasopharyngeal carcinomas. In advances disease stages the EBV DNA levels are higher than in early stages (18).

Epstein-Barr virus has also been studied in OSCC patients, though the results are controversial. According to some investigators, $\mathrm{EBV}$ is associated to OSCC and this association seems to be enhanced by betel quid chewing, thus suggesting that EBV may be an important etiological risk factor for OSCC (19). Furthermore, Jiang et al. (20) described a high prevalence of human papillomavirus (HPV)/EBV infection and coinfection in non-cancerous base of tongue (BOT) lesions and tonsil malignancies, possibly reflecting their origins in lymphoid-rich tissue (20).

In contrast, other authors have found no significant OSCC risk in subjects with EBV infection $(21,22)$. Like- 
Table 1. Epstein-Barr virus DNA findings among the three groups.

\begin{tabular}{|c|c|c|c|c|c|}
\hline Case & Group & Age & Gender & Type of lesion & EBV + DNA \\
\hline 1 & Cancer & 60 & 2 & Ulceration & - \\
\hline 2 & Cancer & 77 & 1 & Ulceration & - \\
\hline 3 & Cancer & 79 & 1 & Ulceration & + \\
\hline 4 & Cancer & 60 & 2 & Ulceration & + \\
\hline 5 & Cancer & 69 & 2 & Ulceration & + \\
\hline 6 & Cancer & 61 & 1 & Ulceration & - \\
\hline 7 & Cancer & 73 & 1 & Ulceration & + \\
\hline 8 & Cancer & 80 & 2 & Ulceration & + \\
\hline 9 & Cancer & 88 & 1 & Ulceration & + \\
\hline 10 & Cancer & 84 & 1 & Ulceration & - \\
\hline 11 & Cancer & 75 & 2 & Ulceration & + \\
\hline 12 & Cancer & 51 & 2 & Ulceration & - \\
\hline 13 & PMD & 55 & 1 & Verrucous leukoplakia & - \\
\hline 14 & PMD & 74 & 1 & Verrucous leukoplakia & - \\
\hline 15 & PMD & 86 & 1 & Verrucous leukoplakia & + \\
\hline 16 & PMD & 82 & 1 & Verrucous leukoplakia & - \\
\hline 17 & PMD & 67 & 1 & Verrucous leukoplakia & + \\
\hline 18 & PMD & 76 & 1 & Verrucous leukoplakia & - \\
\hline 19 & PMD & 63 & 1 & Verrucous leukoplakia & + \\
\hline 20 & PMD & 62 & 2 & Verrucous leukoplakia & + \\
\hline 21 & PMD & 80 & 1 & Verrucous leukoplakia & - \\
\hline 22 & PMD & 69 & 2 & Homogeneous leukoplakia & - \\
\hline 23 & PMD & 48 & 1 & Homogeneous leukoplakia & + \\
\hline 24 & PMD & 56 & 1 & Homogeneous leukoplakia & - \\
\hline 25 & Control & 58 & 2 & No lesions & - \\
\hline 26 & Control & 48 & 1 & No lesions & - \\
\hline 27 & Control & 71 & 1 & No lesions & - \\
\hline 28 & Control & 74 & 2 & No lesions & - \\
\hline 29 & Control & 43 & 2 & No lesions & + \\
\hline 30 & Control & 68 & 1 & No lesions & - \\
\hline 31 & Control & 77 & 2 & No lesions & - \\
\hline 32 & Control & 73 & 1 & No lesions & + \\
\hline 33 & Control & 57 & 2 & No lesions & - \\
\hline 34 & Control & 50 & 2 & No lesions & - \\
\hline 35 & Control & 49 & 2 & No lesions & - \\
\hline 36 & Control & 58 & 2 & No lesions & + \\
\hline 37 & Control & 47 & 1 & No lesions & - \\
\hline 38 & Control & 75 & 1 & No lesions & + \\
\hline 39 & Control & 46 & 1 & No lesions & + \\
\hline 40 & Control & 76 & 2 & No lesions & - \\
\hline 41 & Control & 50 & 1 & No lesions & + \\
\hline 42 & Control & 54 & 2 & No lesions & + \\
\hline 43 & Control & 48 & 1 & No lesions & - \\
\hline 44 & Control & 53 & 1 & No lesions & + \\
\hline 45 & Control & 63 & 1 & No lesions & - \\
\hline 46 & Control & 46 & 1 & No lesions & - \\
\hline 47 & Control & 81 & 2 & No lesions & - \\
\hline 48 & Control & 65 & 1 & No lesions & + \\
\hline 49 & Control & 30 & 2 & No lesions & - \\
\hline 50 & Control & 28 & 2 & No lesions & + \\
\hline 51 & Control & 75 & 1 & No lesions & + \\
\hline 52 & Control & 70 & 1 & No lesions & + \\
\hline 53 & Control & 25 & 2 & No lesions & + \\
\hline 54 & Control & 28 & 2 & No lesions & + \\
\hline 55 & Control & 22 & 1 & No lesions & - \\
\hline 56 & Control & 80 & 2 & No lesions & + \\
\hline 57 & Control & 27 & 2 & No lesions & + \\
\hline 58 & Control & 35 & 1 & No lesions & - \\
\hline 59 & Control & 46 & 1 & No lesions & - \\
\hline 60 & Control & 22 & 1 & No lesions & - \\
\hline 61 & Control & 42 & 1 & No lesions & - \\
\hline 62 & Control & 25 & 1 & No lesions & + \\
\hline 63 & Control & 29 & 1 & No lesions & - \\
\hline 64 & Control & 37 & 2 & No lesions & - \\
\hline 65 & Control & 34 & 1 & No lesions & - \\
\hline 66 & Control & 19 & 2 & No lesions & - \\
\hline 67 & Control & 56 & 2 & No lesions & - \\
\hline 68 & Control & 36 & 2 & No lesions & - \\
\hline 69 & Control & 53 & 2 & No lesions & - \\
\hline 70 & Control & 35 & 2 & No lesions & + \\
\hline 71 & Control & 50 & 2 & No lesions & + \\
\hline
\end{tabular}

PMD: Potentially malignant disorder

Gender: 1 Female, 2 Male

Cancer: Group 1

PMD: Group 2 
Table 2. Summary of DNA EBV detection in saliva of the three groups.

\begin{tabular}{|c|c|c|c|c|}
\hline & & \multicolumn{2}{|c|}{ Saliva DNA Epstein-Barr virus } & \multirow[b]{2}{*}{ Total } \\
\hline & & \multirow{2}{*}{$\frac{\text { Negative }}{28(59.6 \%)}$} & \multirow{2}{*}{$\begin{array}{c}\text { Positive } \\
19(40.4 \%)\end{array}$} & \\
\hline \multirow{3}{*}{ Groups } & Controls & & & 47 \\
\hline & OSCC & $5(41.7 \%)$ & $7(58.3 \%)$ & 12 \\
\hline & PMD & $7(58.3 \%)$ & $5(41.7 \%)$ & 12 \\
\hline & & Value & \multicolumn{2}{|c|}{ Significance } \\
\hline \multicolumn{2}{|c|}{ Chi square of Pearson } & 1.270 & 0.530 & \\
\hline
\end{tabular}

OSCC: Group 1.

PMD: Group 2.

wise, the data published in 2014 by Saravani et al. (23) neither supported the hypothesis that EBV and HHV-6 are directly involved in OSCC nor ruled out the possibility that these viruses might play an indirect carcinogenic role in this area.

Considering the above discrepancies, we tried to analyze the presence of EBV DNA in the saliva of patients with potentially malignant disorders and oral squamous cell carcinoma. No significant differences were observed among OSCC, PMD and the controls $(p>0.05)$. However, EBV DNA positivity was greater in the OSCC group than in the PMD group or controls (Table 2). Studies with a larger number of cases are required to determine whether such higher percentage EBV DNA positivity in $\mathrm{OSCC}$ is also found in other larger populations.

\section{References}

1. Tugizov SM, Herrera R, Palefsky JM. Epstein-Barr virus transcytosis through polarized oral epithelial cells. J Virol. 2013;87:8179-94.

2. Ueda S, Uchiyama S, Azzi T, Gysin C, Berger C, Bernasconi M, et al. Oropharyngeal group A streptococcal colonization disrupts latent Epstein-Barr virus infection. J Infect Dis. 2014;209:255-64.

3. de França TR, de Albuquerque Tavares Carvalho A, Gomes VB, Gueiros LA, Porter SR, Leao JC. Salivary shedding of Epstein-Barr virus and cytomegalovirus in people infected or not by human immunodeficiency virus 1. Clin Oral Investig. 2012;16:659-64.

4. Shan J, Pow EH, Tsang PC, Perera RA, Kwong DL. Comparison of two laboratory extraction techniques for the detection of EpsteinBarr virus in the saliva of nasopharyngeal carcinoma patients. J Investig Clin Dent. 2014;5:104-8.

5. Grande SR, Imbronito AV, Okuda OS, Pannuti CM, Nunes FD, Lima LA. Relationship between herpesviruses and periodontopathogens in patients with HIV and periodontitis. J Periodontol. 2011;82:1442-52.

6. Sahin S, Saygun I, Kubar A, Slots J. Periodontitis lesions are the main source of salivary cytomegalovirus. Oral Microbiol Immunol. 2009;24:340-2.

7. Dawson DR, Wang C, Danaher RJ, Lin Y, Kryscio RJ, Jacob RJ, et al. Salivary levels of Epstein-Barr virus DNA correlate with subgingival levels, not severity of periodontitis. Oral Dis. 2009;15:554-9.

8. Slots J, Saygun I, Sabeti M, Kubar A. Epstein-Barr virus in oral diseases. J Periodontal Res. 2006;41:235-44.

9. Bilder L, Elimelech R, Szwarcwort-Cohen M, Kra-Oz Z, Machtei EE. The prevalence of human herpes viruses in the saliva of chronic periodontitis patients compared to oral health providers and healthy controls. Arch Virol. 2013;158:1221-6.

10. Bagan JV, Jiménez Y, Murillo J, Poveda R, Díaz JM, Gavaldá C, et al. Epstein-Barr virus in oral proliferative verrucous leukoplakia and squamous cell carcinoma: A preliminary study. Med Oral Patol Oral Cir Bucal. 2008;13:E110-3.
11. Carrard VC, Brouns ER, van der Waal I. Proliferative verrucous leukoplakia; a critical appraisal of the diagnostic criteria. Med Oral Patol Oral Cir Bucal. 2013;18:e411-3.

12. Navazesh M. Methods for collecting saliva. Ann N Y Acad Sci. 1993;694:72-7.

13. Kuhara T, Watanabe D, Ishida N, Tamada Y, Matsumoto Y, Ihira $\mathrm{M}$, et al. Quantitative analysis of shedding of Epstein-Barr virus in saliva from patients with connective tissue diseases: a pilot study. Int J Dermatol. 2013;52:887-90.

14. Descamps V, Avenel-Audran M, Valeyrie-Allanore L, Bensaid B, Barbaud A, AlJawhari M, et al. French Study Group of Cutaneous Drug Adverse Reactions. Saliva polymerase chain reaction assay for detection and follow-up of herpesvirus reactivation in patients with drug reaction with eosinophilia and systemic symptoms (DRESS). JAMA Dermatol. 2013;149:565-9.

15. Verdugo F, Castillo A, Castillo F, Uribarri A. Epstein-Barr virus associated peri-implantitis: a split-mouth study. Clin Oral Investig. 2015;19:535-43.

16. Amornthatree K, Sriplung H, Mitarnun W, Nittayananta W. Effects of long-term use of antiretroviral therapy on the prevalence of oral Epstein-Barr virus. J Oral Pathol Med. 2012;41:249-54.

17. Nikoobakht M, Beitollahi J, Nikoobakht N, Aloosh M, Sahebjamee M, Rezaeidanesh M, et al. Evaluation of Epstein-Barr virus load in saliva before and after renal transplantation. Transplant Proc. 2011;43:540-2.

18. Pow EH, Law MY, Tsang PC, Perera RA, Kwong DL. Salivary Epstein-Barr virus DNA level in patients with nasopharyngeal carcinoma following radiotherapy. Oral Oncol. 2011;47:879-82.

19. Acharya S, Ekalaksananan T, Vatanasapt P, Loyha K, Phusingha $\mathrm{P}$, Promthet $\mathrm{S}$, et al. Association of Epstein-Barr virus infection with oral squamous cell carcinoma in a case-control study. J Oral Pathol Med. 2015;44:252-7.

20. Jiang R, Ekshyyan O, Moore-Medlin T, Rong X, Nathan S, $\mathrm{Gu} \mathrm{X}$, et al. Association between human papilloma virus/EpsteinBarr virus coinfection and oral carcinogenesis. J Oral Pathol Med. 2015;44:28-36.

21. Sand L, Jalouli J. Viruses and oral cancer. Is there a link? Microbes Infect. 2014;16:371-8.

22. Nasher AT, Al-Hebshi NN, Al-Moayad EE, Suleiman AM. Viral infection and oral habits as risk factors for oral squamous cell carcinoma in Yemen: a case-control study. Oral Surg Oral Med Oral Pathol Oral Radiol. 2014;118:566-72.

23. Saravani S, Miri-Moghaddam E, Sanadgol N, Kadeh H, Nazeri MR. Human herpesvirus- 6 and epstein-barr virus infections at different histopathological grades of oral squamous cell carcinomas. Int J Prev Med. 2014;5:1231-8.

\section{Conflict of Interest}

Authors declare no conflicts of interest 